\title{
A Study on Social Entrepreneurship and Innovation: Concepts, Observation, Explanation and Happiness
}

\author{
Dr. J Jose Prabhu
}

Independent Research Associate and Visiting Professor, Department of Entrepreneurship and Innovation, Tamilnadu, India.

To Cite this Article

Dr. J Jose Prabhu, "A Study on Social Entrepreneurship and Innovation: Concepts, Observation, Explanation and Happiness", International Journal for Modern Trends in Science and Technology, Vol. 06, Issue 05, May 2020, pp.: 95-99; https://doi.org/10.46501/IJMTST060516

\section{Article Info}

Received on 24-March-2020, Revised on 29-April-2020, Accepted on 05-May-2020, Published on 08-May-2020.

\section{ABSTRACT}

Ordinary methods for review the social parts of business enterprise are viewed as unacceptable; subsequently, this accentuation is recast as far as the "innovative occasion." The pioneering occasion is molded by groupings of social factors, (for example, ethnic gatherings) and the social and social condition. The enterprising occasion is meant by activity taking, combination of assets, the board, relative independence, and hazard taking. The proposed worldview endeavors to incorporate all variants of the innovative occasion and all factors (situational, social, and individual) related to the occasion. The worldview will respond to two essential inquiries: what achieved the groundbreaking occasion? what's more, why this specific occasion? Negative data, occasions, or removals frequently lead to innovative occasions. The specific move made relies on (1) impression of attractive quality (qualities), and (2) view of attainability. The utility of the worldview lies in its application to inquiries of strategy, chronicled models, and future research. Social entrepreneurs are institutional business visionaries who present choices to get change existing social, political or social request. As expressed by Shapero, A.et al (1982) Gram Vikas is one such association that has built up an imaginative way to deal with breakdown the longstanding conventional and social suspicions about social situation of ladies and other hindered bunches in Indian culture.

KEYWORDS: Social Entrepreneurship, Innovation, Rural Development, Ecosystem, Startup Growth

Copyright (C) 2014-2020 International Journal for Modern Trends in Science and Technology

DOI: https://doi.org/10.46501/IJMTST060516

\section{INTRODUCTION}

Destitution, hunger, youngster work, infection, and absence of education, are a portion of the issues which still weaving machines society. These issues have inundated the general public to such a huge degree that it is beyond the realm of imagination to expect to dispose of them if the obligation rests with few. It must be shared among government, NGOs, companies, business visionaries and open on the loose. With such a social strategic, business visionaries and organizations nowadays are attempting to change the life around the globe and are called social business people. Social business visionaries have consistently existed, however now they have developed in numbers. As a rule, the idea of social business is mistaken for charity or non-benefit associations. Practically speaking, it is a more extensive term and thus, it is critical to comprehend the changing shapes of business 
enterprise. Albeit an developing field of research, social business enterprise is as yet idle and unrecognized in the province of Punjab. The expansive target of present investigation is to know the nature and degree of social business in Punjab. The investigation may go about as a wellspring of inspiration and rule for business people who wish to work for the welfare of society. The word business person is gotten from the French word 'entreprendre', which signifies 'to accomplish something' (Mair, J., Robinson, J., \& Hockerts, K. (Eds.). (2006). While accomplishing something the business person initially comprehends the issue (need), investigate assets and openings and use them to locate a novel, successful and an enduring arrangement. The idea of enterprise and the elements of business visionary changed in each time according to necessities of individuals. In Aristotelian custom, idea of business enterprise was totally not the same as present day. Exchange was considered to be a 'suspect action' or causing 'trouble'. Generation and utilization of farming produce was inside family unit and exchange with outside world was restricted to extravagance products. The materialistic reasoning couldn't rule till medieval time. As entire of society was seen as performing supernaturally appointed jobs, so business enterprise, during that time could scarcely be relied upon to include conspicuously. Henceforth, in old and medieval world financial conditions were static, exchange stifled and innovation completely unevolved. With the development of the cutting edge country conditions of France, Spain and England from the late fifteenth century onwards, rulers started to support political capacity to amass fortune and pay armed forces (Dees, J. G. 1998). The condition additionally improved in the sixteenth and seventeenth hundreds of years. While, in the mid sixteenth century, the word business visionary was applied to the individuals who were occupied with military endeavors, in the seventeenth century it was expanded to cover structural designing exercises, for example, development and fortresses (Martin, R. L., \& Osberg, S. 2007).

\section{BACKGROUND AND IMPROVEMENT OF SOCIAL ENTREPRENEURSHIP}

Weerawardena, J., \& Mort, G. S. (2006) Entrepreneurship, subsequently manages making monetary worth and the financial progress made by these imaginative and objective situated business visionaries, is seen as one of the pointer being developed of a country. In any case, enormous steps made by business visionaries what's more, agents around the globe, are lacking when a huge piece of society is oppressed and is missing even fundamental luxuries. There are various social, monetary and ecological issues which should be tended to at worldwide level. These incorporate issues, for example, an Earth-wide temperature boost, end of neediness, designation of assets to instruction and monetary advancement. The point is to adjust financial development and social advancement on this planet and bring feasible improvement. To operationalise this idea of maintainable improvement, the United Countries characterized a lot of Millennium Development Goals (MDGs) in light of goals embraced by General Assembly in September 2000. The MDGs include eight explicit, quantifiable and monitorable objectives (with 18 targets and 48 explicit markers) for improvement and destitution destruction by 2015 (United Nations General Assembly, 2000). Objectives included human rights, wellbeing, instruction and natural issues. Notwithstanding, by 2002 it had just become certain that in numerous nations the objectives probably won't be come to. As per Millennium Development Objectives Report 2010, 1.4 billion individuals were living under destitution line in 2005. Further, 830 million individuals were seen as undernourished during 2005-2007.

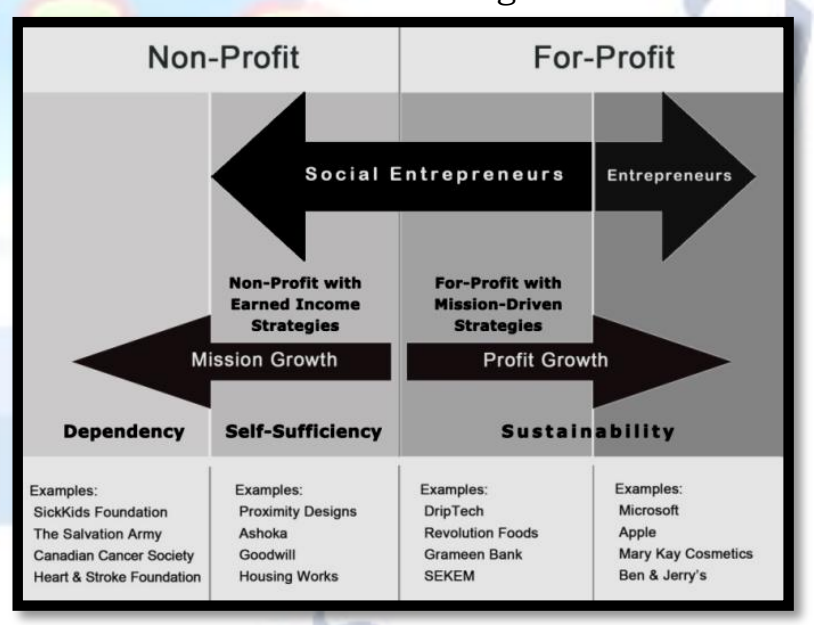

Figure 1: Non-profit and For-Profit Growth : Social Entrepreneurship 


\section{SOCIAL ENTREPRENEURSHIP AND ECOSYSTEM IN INDIA}

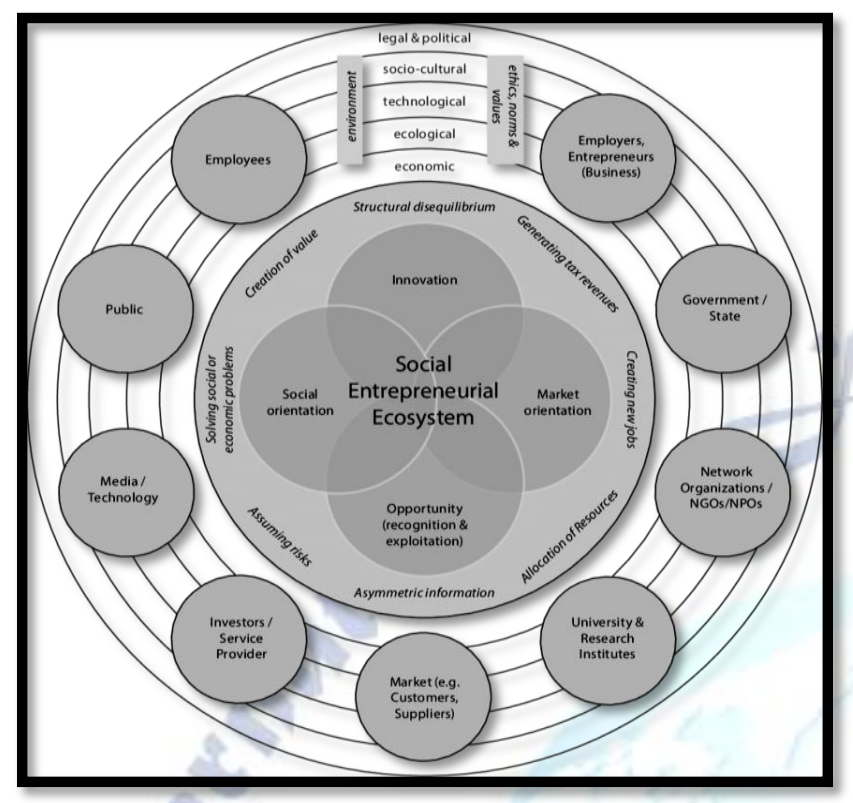

Figure 2 : Social Entrepreneurial Ecosystem in India

Social Entrepreneurs in India are adding to propels in instruction, medicinal services, money related consideration, natural assurance and other social issues. An ongoing effect report discharged by Reach for Change recommend the nearness of positive effect because of social business headways (Light, P. C. 2006).In India it is hard to recognize social endeavors from business ventures on the grounds that there is no different authoritative document for social undertakings. However, various undertakings had the option to expose themselves as social endeavors after they have been working with smaller scale and little venture (MSE), associations, and sole owners. Average case of the social endeavor eco-framework in India incorporates Reach for Change Development Forum, India Social Enterprise, and startup activities are among few (British Council, 2017). As indicated by Capital Newspaper (2016) the Indian Social Entrepreneurship Forum (ISEF) was formally propelled on September, 2016 looking to drive forward a segment with the possibility to change lives the nation over. The discussion intends to unite trailblazers, business visionaries, financial specialists and entertainers from government, organizations, and NGOs who will unite to enable social business people to make enduring constructive change. In Indian setting, Haverkort portrayed social ventures as an undertaking that legitimately addresses social needs through their items and administrations or through the quantities of hindered individuals they utilize. This recognizes social ventures from "socially mindful organizations", which make positive social change in a roundabout way through the act of corporate social duty. In spite of the fact that it is less normal for singular business visionaries to set up a business as a Social Enterprise, there are some settled Social Enterprises in India, that offer items and administrations nearby work and preparing of burdened little fellows and young ladies and they have had a genuine effect in the public eye throughout the years (Haverkort, 2016). There is constrained research on social ventures in Ethiopia (British Council, 2017) that can educate us concerning the practices, difficulties, and chances of social endeavors. Nonetheless, not many investigations (like Social Entrepreneurship, Microfinance and Economic Development in India by Nega and Schneider, 2013; and Indian social endeavor study report dispatched by British Council, 2016) are checked on hereunder. Given the scope of significance social undertakings convey in India, still there are foes who undermine the job of social ventures on neediness mitigation. With this respect, Nega and Schneider (2013) expressed that "social business enterprise could assume a significant job being developed given that social enterprise has restricted potential for auxiliary change and neediness mitigation. Besides, social business enterprise can undermine support for state drove advancement and popularity based changes making social enterprise a valuable microeconomic system that can contribute in little manners to improvement". An examination led by British Council expresses that in India there is no particular authoritative document or enlistment process for social endeavors. In addition, lion's share of the social ventures in the examination territory were found to have been enrolled as MSEs followed by sole ownership, cooperatives, organizations, and philanthropy individually. Another significant boundary revealed in the examination was absence of access to capital while acquiring award support (British Council, 2017). Given the nonattendance of authoritative document for social undertakings, social business visionaries in India should be mindful so as to not befuddle the very quintessence of the social endeavors. As indicated by Mair, J., \& Marti, I. 2006) social business isn't about gatherings, quickening agents, challenges, philanthropy, and magnanimity or riches appropriation. It is about force conveyance among poor people with the goal that they will empower themselves and they will be free of help. 


\section{SOCIAL ENTREPRENEURSHIP AND ORGANIZATION SUPPORT}

There are a few associations around the world which are working for elevating social business to ease the sufferings of individuals. Ashoka: Trend-setters for the Public is one such association. It select the people handling society's most squeezing issues with inventive, enterprising arrangements and furnishing them with living stipends, proficient help and access to a worldwide system of friends in excess of 60 nations. The Schwab Foundation for Social Business enterprise is likewise advancing social business enterprise by tending to the social issues in an imaginative and compelling way. Another significant model is the Establishment of Social Entrepreneurs which is a revenue driven organization. The organization gives instruction, preparing and counseling administrations for social business people in the US and abroad. Network Wealth Ventures is a social undertaking counseling firm that aides non-benefit associations become increasingly self-continuing by making assets through undertakings and corporate associations. Robert Endeavor Development subsidize applies systems intended to make an incentive in the forprofit area to its work with its non-benefit undertakings. It helps organizations and gives business chances to destitute and low-pay people. Further, an association, called Venture Philanthropy Partners is attempting to improve the lives of youngsters from low-pay networks (Peredo, A. M., \& McLean, M. 2006).

\section{ObSERVATION ANd Concepts OF Social ENTREPRENEURSHIP}

Steyaert, C., \& Hjorth, D. (Eds.). 2008). considers about the significant job of private division social enterprise with regards to a state welfare framework extended too far in the red. The four capitals-monetary, social, stylish and natural which can be created or compromised by business people, places social enterprise into a more extensive setting. The creators refered to two past research programs, one by Demos and the other identified with the improvement of the hospice development, which were utilized to help figure various thoughts and proposals. They explored, looked at and differentiated some social innovative cases highlighting visionary and enterprising pioneers who have followed up on the new social open door accessible to them. Social enterprise is the aggregate exertion of individuals with visionary thoughts, individuals with initiative aptitudes and a guarantee to get things going, and individuals focused on helping other people. They examined six cases and found that occasionally the need spread over an entire network, however in different cases it is limited and centered. A few needs are driven by a person's vision, while others by need during the crisis circumstance. Further a few needs were met by people while others by outside organizations, for example, nearby specialists. They inferred that there is obviously both the extension and requirement for increasingly social advancement and social business to meet the recognizable necessities of the network all the more successfully. For this more social victors should be found however the test is to mix individuals - one who have the thoughts, and the other having the will. It was inferred that genuine business people (social) make ocean change developments, either rapidly or after some time and have a significant effect.

\section{Conclusion}

As, the present research work was basically exploratory and enlightening in nature, so at the beginning, the undertaking was to recognize the social enterprising exercises in India. Thusly the information about number or sort of social ventures was not accessible, regardless of whether in government records or dependent on the exploration by any private association. Henceforth, different associations were visited and, cooperations were held with authorities and representatives working there. Additionally, their writing accessible on sites was likewise contemplated. Being a beginning field, individuals are very little acquainted with the idea of social business in India. Any place such work is going on individuals all in all are not ready to distinguish it as a social enterprising action. As social enterprise isn't being rehearsed in the territory of Punjab at an entirely unmistakable level, it was hard to discover its degree. We can infer that whatever objectives a business visionary and pioneering association accomplishes, it can't continue in separation. Its crucial includes the general public on the loose. Subsequently, it should progress for social alongside financial objective. Further, the financial exercises ought to be reached out to accomplish the social objective. Subsequently, the shapes of business enterprise are in this way expanded and these structures the piece of social entrepreneurship. 


\section{REFERENCES}

[1] Shapero, A., \& Sokol, L. (1982). The social dimensions of entrepreneurship. Encyclopedia of entrepreneurship, 72-90.

[2] Mair, J., Robinson, J., \& Hockerts, K. (Eds.). (2006). Social entrepreneurship (p. 3). New York: Palgrave Macmillan.

[3] Dees, J. G. (1998). The meaning of social entrepreneurship.

[4] Martin, R. L., \& Osberg, S. (2007). Social entrepreneurship: The case for definition.

[5] Weerawardena, J., \& Mort, G. S. (2006). Investigating social entrepreneurship: A multidimensional model. Journal of world business, 41(1), 21-35.
[6] Light, P. C. (2006). Reshaping social entrepreneurship. Stanford Social Innovation Review, 4(3), 47-51.

[7] Mair, J., \& Marti, I. (2006). Social entrepreneurship research: A source of explanation, prediction, and delight. Journal of world business, 41(1), 36-44.

[8] Peredo, A. M., \& McLean, M. (2006). Social entrepreneurship: A critical review of the concept. Journal of world business, 41(1), 56-65.

[9] Steyaert, C., \& Hjorth, D. (Eds.). (2008). Entrepreneurship as social change: A third new movements in entrepreneurship book (Vol. 3). Edward Elgar Publishing.

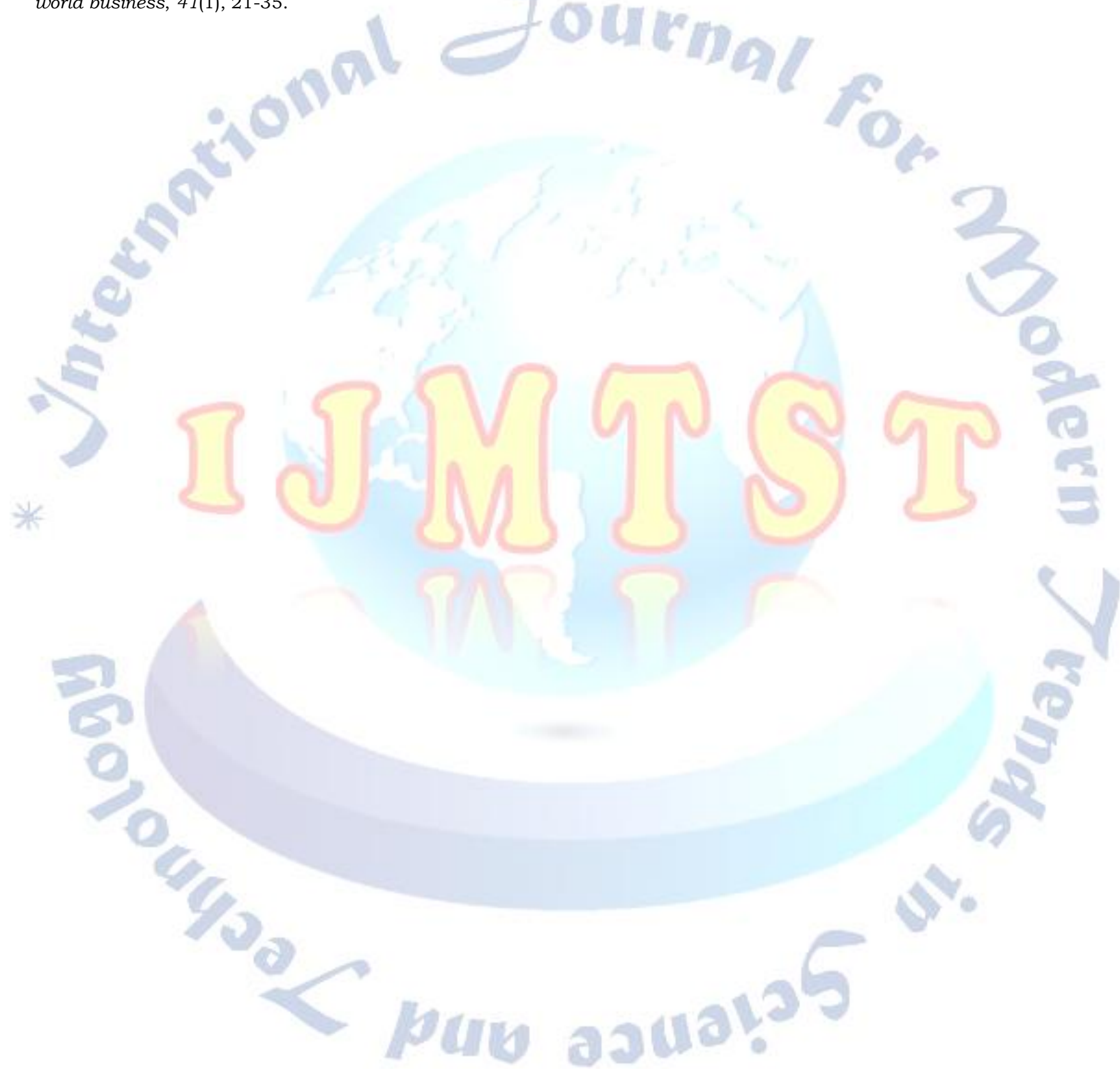

